\title{
EVOLUTION OF THE POLISH FOOD SECURITY AND ITS RESIDENTS AT THE BEGINNING OF THE $21^{\text {sT }}$ CENTURY
}

\begin{abstract}
A people who are dependent on foreigners for food or clothes must always be subject to them.
\end{abstract}

Benjamin Rush (1775)

\begin{abstract}
The aim of the study was to determine the status and direction of changes in food security of Poland and its inhabitants at the beginning of the twentyfirst century, in particular: to characterise the level of consumption of basic food products in 2000-2014 and the level of food self-sufficiency of selected products; to assess the conditions for durability and reliability of food supplies; to characterise the conditions of economic availability of food and the diversity of the Polish inhabitants in this regard; to determine the level of consumption of energy, its structure and basic nutrients for different socio-economic groups of households for 2001-2003 and 2012-2014.

To ensure food security of the state, four conditions must be met simultaneously: (1) physical availability of food, which means that the domestic food economy ensures consumption of at least the minimum physiological requirement, while import of food provides more than this minimum requirement; (2) durability and reliability of food supplies; (3) economic availability of food, which is equivalent to the fact that the economically weakest households and their members have access to the necessary food (due to various forms of food aid); (4) health suitability of a single food product and consumed food ration (the necessary energy level, the proper ratio of nutrients, the lack of an inadmissible degree of pollution).
\end{abstract}

Keywords: food security, self-sufficiency, structure, levels, consumption.

JEL Cods: E2: E21, E23, E24. 


\section{Introduction}

The issue of rational nutrition of the population, and more broadly - food security, has sparked interest among the public for centuries, but only in 1974 following a food crisis - an attempt was made at its definition. Later others tried to clarify the term in: 1983, 1986, 1996 and 2002 (Obiedzińska, 2012).

In 2002, FAO report contained a definition of food security which argued that it "exists when all people, at all times, have physical, social and economic access to sufficient, safe and nutritious food that meets their dietary needs and food preferences for an active and healthy life" (FAO, 2002, as in: Obiedzińska, 2012, p. 10).

Food security has three dimensions: international, including regional (e.g. European Union), state (national), and that of a household, including of its respective members.

This discussion concerns the dimension of food security at the level of a state and a household, especially of its respective members (inhabitants).

To ensure food security of a state the following four conditions have to be met all together (Kapusta, 2003):

1) Physical availability of food means that the national food economy guarantees meeting of at least the minimum physiological requirement, while import provides food exceeding the minimum requirement;

2) Durability and reliability of food supplies;

3) Economic availability of food which means that also the economically weakest households and their members have access to the necessary food (because of various forms of food aid);

4) Health suitability of a single food product and consumed food ration (necessary energy level, proper proportion of nutrients, no unacceptable pollutions).

Two types of the state food security can be differentiated, which can be additionally separated by the time criterion (Schejtman, 1988):

a) Short-term maladaptation of physical food availability resulting from the cyclical deviations of food production from food demand;

b) Long-term maladaptation of physical food availability caused by fixed and increasingly more frequent gaps between food production and food demand;

c) Short-term maladaptation of economic food availability (cyclical or seasonal) resulting from income difficulties of households;

d) Long-term maladaptation of economic food availability resulting from a fixed gap between the food needs and income available to satisfy the needs in a given social group.

Today (in the conditions of global economy), no country should gear for full self-sufficiency as each country has its own specific set of food production conditions, which in some sectors gives it advantage on the global markets, and in others makes it uncompetitive. National food security is met when - at the existing level of consumption - equilibrium in trade in food products is sustained. 
This state is identified with the use of the self-sufficiency (Ss) ratio (Kapusta, 2012). Nonetheless, it is required to drive at consumption level recommended by science at complete equilibrium of trade turnover, i.e. security optimum.

The concepts of the national food security and food self-sufficiency complement each other. But, self-sufficiency is narrowed down to strategic products (raw materials) and concentration on optimum use of the potential of the national food economy, continually confronted with the international market of means of production, raw food and final food. Whereas the concept of food security concerns primarily the consumption area (level, structure, health quality of consumed food) and the allocation area, which decides on whether or not also the economically weakest households, and especially their members, benefit from access to necessary food requirement.

Food security of a household and its members is preconditioned by the same conditions as that of the national food security. But there is still a specificity to them which follows from the fact that a household is a basic entity in the consumption area, but of low level of organisation. Attention, at this point, should be drawn by professional activity of the members of a household, their education, position on the labour market and fixed income.

Food policy conducted by the state is primarily oriented at rationalisation of food consumption. To this end, the state launches a set of measures to inform the consumer on methods and possibilities of rationalisation. Decisions on how to use the information are made in households, where accordingly to the education level, tradition and habits, the process of food consumption is rationalised.

When analysing food security on the level of a household, it is clear that there is a discrepancy between the economic security of the household and food allocation among family members. Today, this discrepancy appears where malnutrition of children and other family members results from the need to provide better nourishment to a hard-working family member. Although this method of allocation - dictated by poverty - increases the ad hoc economic security and thus food security of a household, reduction of food rations for children and women (especially pregnant and nursing) threatens a long-term biological development of a family. Consequently, biological development of a large part of the society is endangered.

This discrepancy makes it necessary to provide various forms of food aid to economically weak households (food coupons, out-of-home feeding of children and pregnant and nursing women, etc.).

There are increasingly more papers in literature on the issue of food security, discussing its lack or existence in different countries and across different communities and social classes. Economic security of a country gives it an important political and economic advantage. Many internal conflicts in modern world are caused by its lack (e.g. some African countries, Syria). Moreover, this lack results in malnutrition and hunger. 
Works that should be especially emphasised in Polish literature include the papers by Małysz $(1991,2008)$, which contain a multi-aspect analysis of the issues concerning food, its availability and assessment of the state policy in the field of ensuring food security. Issues of food security are also researched by the employees of the Institute of Agriculture and Food Economy (e.g.: Michna, 1998; Kwasek (ed.), 2012; Gulbicka, 2003) and university researchers (e.g.: Małysz, 1990, 2009; Michalczyk, 2012; Mikuła, 2012; Leśniak, 2012; Sapa, 2012; Kapusta, 2015). The above-mentioned authors fail to include durability and reliability of food supplies among the elements of the national food security. So far, this issue has been covered only by the works of Kapusta $(2003 ; 2008$; 2012 ; 2015). It is an important element of security, because of the specificity of food and its role in meeting the needs of people. Food is consumed continually on a one-off basis. Disruptions in the functioning of a food chain cause panic on the market of food products, triggering an increase in purchases, and thus further disruptions in the food chain functioning. The issues of food security were also introduced into academic textbooks, e.g. Kapusta $(2003 ; 2008 ; 2012)$.

\section{Research aim, scope and methodology}

The research aimed at determining the status and direction of changes to food security of Poland and its inhabitants at the beginning of the $21^{\text {st }}$ century, in particular:

a) Characterisation of the level of consumption of the basic food products in 2000-2014 and determining the level of food self-sufficiency of selected products.

b) Assessment of the conditions of durability and reliability of food supplies.

c) Characterisation of the conditions of economic availability of food and differentiation of the Polish society in this regard.

d) Determining the level of energy consumption, its structure and basic nutrients for respective socio-economic groups of households in 2001-2003 and 2012-2014. Three-year periods and their averages were adopted to eliminate annual consumption fluctuations. Because the number of Polish families changes over time (drops), the research used the consumption level per 1 family member.

The study uses compact and continuous academic publications and statistical materials from the Central Statistical Office [Główny Urząd Statystyczny, GUS] and reports of the Institute of Agriculture and Food Economics - National Research Institute.

Table 1 presents the set of measures and indices to assess the status of national food security of Poland and its inhabitants. 
Table 1

Measures and indices of food security assessment for a country and its inhabitants

\begin{tabular}{|c|c|c|}
\hline $\begin{array}{l}\text { Measurement } \\
\text { type }\end{array}$ & Measures & Indices \\
\hline $\begin{array}{l}\text { I. Physical } \\
\text { food } \\
\text { availability }\end{array}$ & $\begin{array}{l}\text { - consumption of food products } \\
\text { in weight units }\end{array}$ & $\begin{array}{l}\text { - consumption of food products } \\
\text { in } \mathrm{kg} / \mathrm{capita} / \mathrm{year} \\
\text { - consumption of food products } \\
\text { in } \mathrm{kg} / \mathrm{capita} / \text { year/recommended } \\
\text { consumption level }\end{array}$ \\
\hline $\begin{array}{l}\text { II. Durability } \\
\text { and reliability } \\
\text { of food } \\
\text { supplies }\end{array}$ & $\begin{array}{l}\text { - foreign trade in agri-food } \\
\text { products } \\
\text { - a retail chain with food } \\
\text { products }\end{array}$ & $\begin{array}{l}\text { - volume of export of agri-food products } \\
\text { (USD, EUR, PLN)/capita/year } \\
\text { - volume of import of agri-food products } \\
\text { (USD, EUR, PLN)/capita/year } \\
\text { - trade balance in (USD, EUR, PLN)/ } \\
\text { capita/year } \\
\text { - population figure per } 1 \text { store } \\
\text { - population figure per } 1 \text { big-box store }\end{array}$ \\
\hline $\begin{array}{l}\text { III. Economic } \\
\text { food availability }\end{array}$ & - amount of disposable income & $\begin{array}{l}\text { - amount of disposable income/capita/ } \\
\text { month } \\
\text { - increase in disposable income }(\%) \\
\text { - expenditure on food and non-alcoholic } \\
\text { beverages PLN/capita/month } \\
\text { - increase in expenditures on food and } \\
\text { non-alcoholic beverages in \% } \\
\text { - expenditures on food and non-alcoholic } \\
\text { beverages in \% of disposable income } \\
\text { - changes in expenditures (+-) }\end{array}$ \\
\hline $\begin{array}{l}\text { IV. Health } \\
\text { suitability of } \\
\text { a single product }\end{array}$ & $\begin{array}{l}\text { - content of nutrients in products } \\
\text { - calorific value of products }\end{array}$ & $\begin{array}{l}\text { - calorific value of the diet in kJ } \\
\text { - energy structure in \% } \\
\text { - nutrients (g): total protein (animal, } \\
\text { vegetable), fats, carbohydrates }\end{array}$ \\
\hline
\end{tabular}

Source: own study.

The collected material was processed and interpreted with the use of the following methods: vertical, horizontal, balance and model (reference) (Kapusta, 1976; Stachak, 2003) comparative method and statistical method (Stachak, 1997). Meeting the condition for manufacturing sufficient amount of feeding products was researched with the food self-sufficiency $(S s)$ ratio (Kapusta, 2012).

This index is the quotient of national production $(P k)$ and national consumption $(Z k)$ (in this case: consumption, reproduction, industrial consumption, animal feeding and losses and shortages) according to the formula: 


$$
S_{s}=\frac{P k}{Z k} \times 100
$$

where:

Ss - self-sufficiency level,

$P k$ - national production,

$Z k$ - national consumption.

National production balance or margin in national consumption evidences sufficient production and is considered as sustainable production and consumption $(S s=100$ or $<100)$.

The tables present the obtained research results.

\section{Results and discussion}

\section{(a) Level of consumption of basic food products versus food security}

Table 2 shows changes in the level of consumption of basic food products in Poland between 2000 and 2014 enumerating the change ratios (data for 2000 are treated as reference for comparison of change dynamics). From this it follows that except for meat and offal, sugar and milk and its products, consumption of the remaining products decreased. The stable tendencies are noted at this point, e.g. cereals, potatoes, whereas fluctuations as regards the direction, e.g., chicken eggs, sugar, fruit - determined by the production level (e.g. vegetables, fruit) and the price for consumed products (e.g. chicken eggs - in 2011 and 2012).

The level of consumption of products by the population not always influences the degree of self-sufficiency of Poland and its range (Table 3 ).

This is because the agricultural products are intended not only for consumption by the population but also for fodder for animals and for industrial processing into non-food products. Cereals are a good example, as their production grows and the share of human consumption - drops, and the level of self-sufficiency of the country is not kept each year, mainly due to a tight fooder balance.

There is at least one more conclusion following from Table 3, namely that production, especially plant production, shows quite significant fluctuations in its size from year to year, while changes in the level of consumption by the population are rather slow. This forces the need either to have stocks of raw materials or processed products, or to purchase products abroad. 
$\frac{\sqrt{\frac{0}{0}}}{\frac{0}{2}}$

ఫી

๙

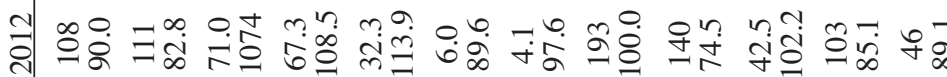

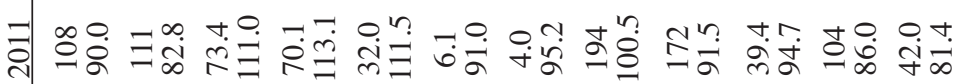

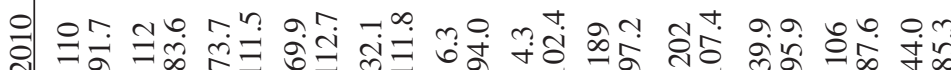

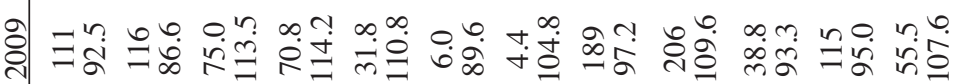

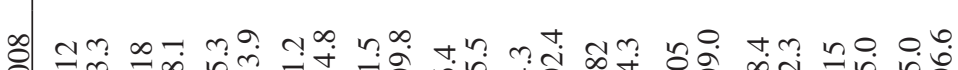

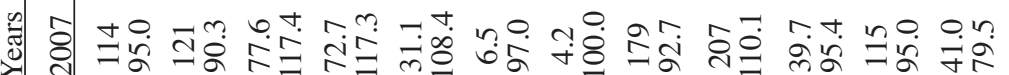

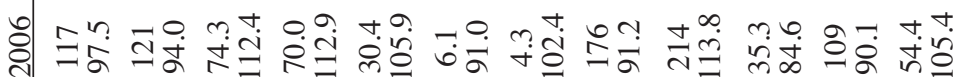

そุ:

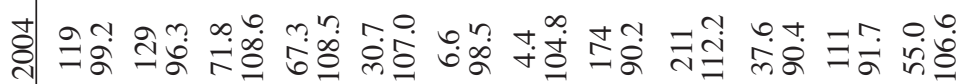

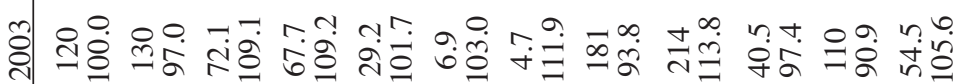

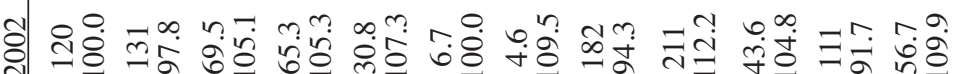

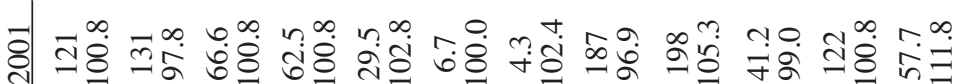

위 융 ஸे

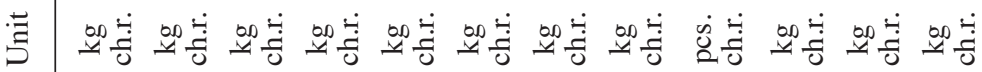

氖

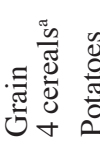

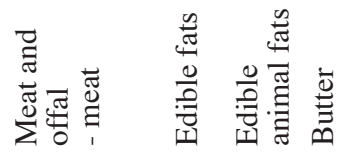

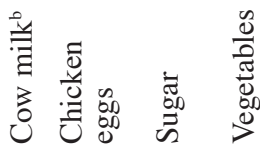

i 
Table 3

Level of food self-sufficiency on the example of selected products

(production in thousand tonnes, consumption in \% of production)

\begin{tabular}{|c|c|c|c|c|c|c|c|c|c|c|c|c|c|}
\hline \multirow{2}{*}{ Specification } & \multicolumn{13}{|c|}{ Years } \\
\hline & 2001 & 2002 & 2003 & 2004 & 2005 & 2006 & 2007 & 2008 & 2009 & 2010 & 2011 & 2012 & 2013 \\
\hline \multicolumn{14}{|l|}{ 1. Cereals } \\
\hline Consumption (\%) & 22.5 & 23.1 & 24.6 & 21.0 & 22.8 & 25.9 & 20.7 & 20.2 & 18.4 & 20.8 & 21.9 & 20.7 & 20.5 \\
\hline Ss & 101.9 & 97.1 & 91.5 & 114.4 & 98.7 & 82.5 & 103.8 & 103.9 & 110.7 & 100.6 & 97.1 & 103.4 & 106.8 \\
\hline \multicolumn{14}{|l|}{ 2. Potatoes } \\
\hline Yields & 19379 & 15524 & 13731 & 13999 & 13999 & 10369 & 8982 & 11791 & 10462 & 9703 & 8448 & 9362 & 7290 \\
\hline Consumption (\%) & 25.9 & 32.3 & 36.1 & 35.3 & 35.3 & 46.5 & 51.2 & 39.1 & 43.0 & 45.6 & 50.4 & 46.2 & 54.1 \\
\hline Ss & 99.3 & 102.5 & 102.8 & 101.8 & 101.8 & 104.5 & 100.5 & 98.1 & 97.8 & 104.9 & 94.9 & 96.9 & 105.5 \\
\hline \multicolumn{14}{|l|}{ 3. Sugar } \\
\hline Production & 1543 & 2032 & 1949 & 2002 & 2002 & 2047 & 1723 & 1934 & 1351 & 1674 & 1629 & 1943 & 1952 \\
\hline Consumption (\%) & 94.6 & 68.3 & 78.0 & 54.6 & 54.6 & 70.5 & 74.9 & 73.4 & 92.5 & 71.8 & 96.5 & 64.3 & 65.6 \\
\hline Ss & 102.5 & 141.9 & 124.8 & 176.5 & 148.6 & 143.0 & 129.4 & 130.2 & 102.7 & 122.9 & 98.9 & 68.2 & 143.8 \\
\hline \multicolumn{14}{|l|}{ 4. Vegetables } \\
\hline $\begin{array}{l}\text { Yields } \\
\text { Consur }\end{array}$ & 5575 & 4069 & 5091 & 5590 & 5590 & 5458 & 5120 & 5710 & & $\begin{array}{l}5601 \\
818\end{array}$ & $\begin{array}{l}4878 \\
837\end{array}$ & $\begin{array}{l}5575 \\
793\end{array}$ & 4986 \\
\hline Ss & 102.7 & 108.0 & 110.9 & 105.1 & 105.1 & 112.5 & 108.2 & 112.2 & 109.7 & 108.1 & 93.8 & 93.1 & 103.7 \\
\hline \multicolumn{14}{|c|}{ 10- - } \\
\hline Yields & 3405 & 3009 & 3298 & 3511 & 2922 & 3211 & 1684 & 3826 & 3646 & 2744 & 3415 & 3843 & 4128 \\
\hline Consumption (\%) & 93.9 & 99.0 & 92.3 & 90.8 & 98.8 & 91.2 & 117.2 & 87.4 & 87.3 & 102.5 & 86.3 & 77.6 & 75.5 \\
\hline Ss & 90.6 & 92.6 & 93.7 & 95.7 & 88.3 & 94.9 & 73.8 & 98.9 & 98.4 & 84.5 & 100.3 & 115.0 & 111.7 \\
\hline \multicolumn{14}{|l|}{ 6. Cow milk } \\
\hline Production & 11538 & 11527 & 11546 & 11477 & 11575 & 11633 & 11744 & 12063 & 12085 & 11921 & 12052 & 12299 & 12607 \\
\hline Consumption (\%) & 86.5 & 87.5 & 85.8 & 79.0 & 76.4 & 775 & 77.1 & 76.5 & 80.0 & 80.2 & 79.9 & 78.1 & 80.5 \\
\hline Ss & 108.6 & 106.8 & 109.1 & 119.0 & 123.0 & 120.0 & 122.0 & 123.0 & 118.5 & 117.6 & 118.6 & 120.6 & 117.3 \\
\hline \multicolumn{14}{|l|}{ 7. Chicken eggs } \\
\hline & 451 & 499 & 518 & 521 & 545 & 546 & 556 & 590 & 614 & 637 & 587 & 538 & 577 \\
\hline Consumption (\%) & 93.3 & 89.6 & 86.3 & 85.8 & 82.0 & 79.3 & 70.1 & 69.5 & 68.6 & 66.2 & 61.3 & 55.2 & 51.1 \\
\hline & 100.7 & 102.3 & 105.7 & 105.0 & 109.4 & 112.1 & 124.1 & 126.3 & 127.7 & 129.5 & 137.1 & 153.4 & 155.1 \\
\hline
\end{tabular}

Note: for plant products data for the following years: 2001/02, 2002/03, 2003/04, 2004/2005, 2005/2006, 2006/2007, 2007/2008, 2008/2009, 2009/2010, 2010/2011, 2011/2012, 2012/13, 2013/14; Ss - self-sufficiency ratio.

Source: GUS (2005), pp. 385-386; GUS (2006), p. 406; GUS (2007), pp. 383, 392; 2008, p. 393, 402; GUS (2009), p. 299-300; GUS (2010), pp. 297-299, 308; GUS (2013), pp. 319-320; GUS (2010), p. 518; GUS (2011), pp. 468-469; GUS (2015), pp. 325-329, 336; own calculations.

Assessing the first condition of food security of Poland on the example of selected products, it needs to be stated that it is sustained for a definite majority of products with a margin (level Ss $>100$ ). The only exception is fruit, for which the Ss ratio only in 2011-2013 is higher than 100. Having a margin over consumption creates possibilities to export the excess quantity of manufactured prod- 
ucts, and to import for the obtained foreign currency products manufactured in a given year in an insufficient amount or products which are not manufactured in the country for natural reasons (e.g. some vegetables and fruit).

\section{(b) Assessment of the conditions of durability and reliability of food supplies}

The issue of durability and reliability of supplies is assessed on the basis of food chain functioning. Positive trade balance in agri-food products (Poland has it since 2003) gives economic grounds for shaping durability and reliability of food supplies and extend the range of supplied products. In 2003-2013, the export value per capita increased form EUR 104.98 to EUR 530.58, i.e. by $454.1 \%$, while that of import from EUR 93.11 to EUR 371.75, i.e. by $299.3 \%$. But then, export margin over import increased from EUR 11.87 to EUR 158.83, i.e. by $1238.1 \%$ (IERiGŻ, ARR, MRiRW: Handel, 2004; MarksBielska et al., 2015).

When assessing the durability and reliability of food supplies, what matters is not only the quantitative aspect of food products but also its range and quality aspect. For a household, everyday availability of food goods is important. To this end, the system of physical availability of food products is continually improved, e.g. by verification of the retail chains and outlets, better system of supply of stores and improved level of customer service (Kapusta, 2006). For example, in 2000 there were 89 inhabitants per 1 store and in 2014 - 108 inhabitants (GUS, 2004; 2015). Apart from stores there are also sale outlets for which there is almost half less people per 1 sale outlet than per 1 store. The number of stores of larger sales area gradually increases; in 2005 there were 544 stores of $2500 \mathrm{~m}^{2}$ and more, and in 2014 there were 986 of them (GUS, 2014). If in 2005, there were 70221 inhabitants per 1 big-box store, then in 2014 there were only 39047 people, i.e. by $44.4 \%$ less. A growth in the number of stores of larger area is to create durability and sustainability of supplies both as regards quantity and range of products, and the competition existing between the stores contributes to the growth in service quality, price reduction and better quality of goods.

\section{(c) Assessment of economic availability of food}

Economic availability of food depends on obtaining fixed income and on the level of disposable income per family member. The higher the disposable income level, the less is spent on food (Engel's law). Table 4 compares changes in the average disposable income, expenditure on food and non-alcoholic beverages per 1 family member in 2001-2003 and 2012-2014 and averages for the periods. 
Table 4

Changes in the average disposable income, expenditures on food and non-alcoholic beverages in households in 2001-2003 and 2012-2014 (monthly per capita in a household)

\begin{tabular}{|c|c|c|c|c|c|c|}
\hline \multirow[b]{2}{*}{ Specification } & \multirow{2}{*}{ Year } & \multirow{2}{*}{ Total } & \multicolumn{4}{|c|}{ Households } \\
\hline & & & employees & farmers & $\begin{array}{c}\text { self- } \\
\text {-employed }\end{array}$ & pensioners \\
\hline \multirow[t]{8}{*}{ Disposable income (PLN) } & 2001 & 644.48 & 683.07 & 497.54 & 808.22 & 673.89 \\
\hline & 2002 & 664.21 & 698.09 & 571.83 & 843.24 & 699.02 \\
\hline & 2003 & 680.50 & 729.87 & 474.31 & 860.20 & 720.00 \\
\hline & average & 663.06 & 703.68 & 514.56 & 837.55 & 697.64 \\
\hline & 2012 & 1278.43 & 1289.16 & 1091.55 & 1536.68 & 1297.90 \\
\hline & 2013 & 1299.07 & 1305.87 & 1156.13 & 1581.05 & 1328.65 \\
\hline & 2014 & 1340.44 & 1349.12 & 1050.85 & 1631.64 & 1382.32 \\
\hline & average & 1305.98 & 1314.72 & 1099.51 & 1583.12 & 1336.29 \\
\hline $\begin{array}{l}\text { Increase in disposable } \\
\text { income }(\%)\end{array}$ & $\mathrm{x}$ & 197.0 & 186.8 & 213.7 & 189.0 & 191.5 \\
\hline \multirow{8}{*}{$\begin{array}{l}\text { Expenditure on food } \\
\text { and non-alcoholic } \\
\text { beverages (PLN) }\end{array}$} & 2001 & 188.74 & 178.39 & 189.98 & 197.36 & 217.07 \\
\hline & 2002 & 184.61 & 173.61 & 190.27 & 195.59 & 212.04 \\
\hline & 2003 & 182.13 & 172.34 & 185.96 & 191.60 & 209.33 \\
\hline & average & 185.16 & 174.78 & 188.74 & 194.85 & 212.81 \\
\hline & 2012 & 263.85 & 247.44 & 249.87 & 273.14 & 312.98 \\
\hline & 2013 & 264.36 & 248.81 & 246.99 & 273.40 & 314.88 \\
\hline & 2014 & 263.34 & 246.80 & 247.73 & 271.70 & 314.54 \\
\hline & average & 263.85 & 247.68 & 248.20 & 272.75 & 314.13 \\
\hline Increase in expenditures $(\%)$ & $\mathrm{x}$ & 142.5 & 141.7 & 131.5 & 140.0 & 147.6 \\
\hline \multirow{2}{*}{$\begin{array}{l}\text { and non-alcoholic beverages } \\
(\%) \text { of disposable income }\end{array}$} & 2001-2003 & 27.9 & 24.8 & 36.7 & 23.3 & 30.5 \\
\hline & $2012-2014$ & 20.2 & 18.8 & 22.6 & 17.2 & 23.5 \\
\hline Changes (+-) & $\mathrm{x}$ & -7.7 & -6.0 & -14.1 & -6.1 & -7.0 \\
\hline
\end{tabular}

Source: GUS (2003), pp. 203-208; GUS (2004), pp. 290-295; GUS (2014), pp. 302-303; GUS (2015), pp. 304-305.

From Table 4 it follows that:

- The level of disposable income for households is differentiated; it is the highest in households of self-employed people, and the lowest in households of farmers.

- Disposable income grows, but the growth is not always linear, and the rate of these changes is uneven for respective groups of households - it is the greatest for households of farmers (213.7\%), while the lowest for households of 
employees (186.8\%). Despite such growth rate of changes in households of farmers this income in 2012-2014 was the lowest.

- Expenditures on food and non-alcoholic beverages show a growth - also non-linear. The highest dynamics was noted for households of pensioners (147.6\%), and the lowest for households of farmers (131.5\%).

- The share of expenditures on food and non-alcoholic beverages in the disposable income decreased the most for households of farmers (-14.1 pp) and the least for households of employees (-6.0 pp). In 2012-2014, the highest amount of expenditures on food and non-alcoholic beverages from the disposable income was allocated by households of pensioners $(23.5 \%)$, and the lowest - households of self-employed persons (17.2\%).

Disposable income and expenditures on food and non-alcoholic beverages are different not only between social and professional groups of the population but also inside the groups (Kwasek, 2012).

In 2011, the average monthly disposable income of households in total in Poland for $20 \%$ of people achieving the highest income $\left(5^{\text {th }}\right.$ quintile group) amounted to PLN 2560.29 and was 6.4 times higher than the similar income for $20 \%$ of people achieving the lowest income ( $1^{\text {st }}$ quintile group). For households in total, $20 \%$ of people in the best income situation had at their disposal $41.7 \%$ of income of the entire researched group of households, while $20 \%$ of people in the worst income situation $-6.5 \%$ (Kwasek, 2012). The differences refer also to expenditures on goods and consumer services (hereinafter food series). In the $5^{\text {th }}$ quintile group they were 2.2 times higher than in the $1^{\text {st }}$ group (of the lowest income). If in the entire researched group the food expenditure constituted $22.5 \%$ of disposable income, then in the lowest income group it was $46.1 \%$ and in the highest $16.0 \%$. The income elasticity coefficient of food expenditure is high, which may mean that in this group of population the food needs are unsatisfied (Kwasek, 2012).

The income situation of households has a major impact on the differentiation of the level of food consumption. Along with a growth in income, the level of consumption of the basic food products also increases, except for the consumption of bread, whole milk, animal fats (excluding butter), margarine and other vegetable fats and potatoes. Consumption of pigmeat, poultry, vegetable oils and sugar grows up to the $4^{\text {th }}$ quintile group and only in the $5^{\text {th }}$ quintile group it drops (Kwasek, 2012).

The state develops varied forms of aid to availability of food for people without fixed income and with low income, but - as it follows from the above-mentioned research - they are insufficient and require changes. There are still households at risk of poverty, whose share in relative and statutory poverty in 2010-2014 decreases, while that of households with minimum existence - grows (GUS, 2015). 


\section{(d) Setting the level of energy consumption, its structure and food quality}

Calculation of the quantitative food consumption into calorific value and nutrients for households showed that in the analysed period in all socio-economic groups the calorific value of a diet decreases. The highest value is still noted for households of pensioners, followed by that of farmers and the lowest for households of self-employed people (Table 5).

In all socio-economic groups the calorific value of the diet is at the level of recommended value (9200-11 $700 \mathrm{~kJ}$ ), except for the group of employees and self-employed people in 2012-2014. Structure of this diet is unfortunately faulty, because the recommended structure of energy should amount to: protein 10-15\%, fats 25-35\%, carbohydrates 50-70\% (Jarosz (ed.), 2012). The structure in 2001-2003 was more sustainable than in 2012-2014.

In the second of the researched periods, only energy from protein is within the recommended limits, while there is too much energy from fats and too little from carbohydrates (except for the group of farmers - 50.9\% - lower limit of the recommended standard).

The quality of nutrition is predetermined not only by the calorific value of a diet but also by the consumption of the basic nutrients. Protein consumption, including animal protein, deserves a special attention in average daily food consumption. In the analysed years in all socio-economic groups the quantities of consumed protein only slightly decreased except for households of employees and self-employed people. The changes in the level of animal and plant protein consumption are shaped differently - animal protein consumption (except for the households of farmers) grows, while that of plant consumption in all groups decreases.

What decreased in all groups was the quantity of consumed fats and carbohydrates. If a drop in the consumption of fats is desired, than that of carbohydrates is not recommended, which is evidenced by the structure of obtained energy. All in all, a change in the structure of obtained energy is achieved as a result of asymmetric reduction in consumption of basic food products.

Apart from the content of the basic foods in nutrition, it is also important to remember about the purity of food in terms of pollution. The Act on food security and food safety (Act, 2006, 2008) determines the requirements and procedures necessary to ensure food security and food safety in line with the Community law. The issues of food security in Poland was researched by Gulbicka (2008); Kowalczyk (2009); Mikuła (2012) and many more authors. These authors state that food security in Poland is at a high and still increasing level. In Poland, official food control is exercised by five specialised inspections, three dealing with security and safety: State Sanitary Inspection, Veterinary Inspection and Main Inspectorate of Plant Health and Seed Inspection, and two dealing with trade quality: Trade Inspection (in retail trade) and Main Inspectorate of Agricultural and Food Quality Inspection (Kapusta, 2012). 
Table 5

Average daily consumptiona converted into calorific value and nutrients per capita in households in 2001-2003 and 2012-2014

\begin{tabular}{|c|c|c|c|c|c|c|}
\hline \multirow{2}{*}{ Specification } & \multirow{2}{*}{ Rok } & \multicolumn{5}{|c|}{ Households } \\
\hline & & total & employees & farmers & self-employed & pensioners \\
\hline \multirow[t]{4}{*}{ Calorific value (kJ) } & 2001 & 10344 & 9296 & 11549 & 9434 & 11879 \\
\hline & 2002 & 10305 & 9355 & 11595 & 9495 & 11608 \\
\hline & 2003 & 10344 & 9296 & 11549 & 9434 & 11879 \\
\hline & average & 10331 & 9316 & 11564 & 9454 & 11789 \\
\hline \multirow[t]{5}{*}{ Energy structure $(\%)^{\mathrm{b}}$} & $\mathrm{x}$ & $11.9: 36.1: 52.0$ & $12.1: 36.7: 51.2$ & $11.7: 35.5: 52.8$ & 12.3:37.3:50.4 & - $11.9: 35.9: 52.2$ \\
\hline & 2012 & 9574 & 8986 & 9935 & 9093 & 10861 \\
\hline & 2013 & 9155 & 8628 & 9399 & 8737 & 10387 \\
\hline & 2014 & 9546 & 8999 & 9641 & 9115 & 10737 \\
\hline & average & 9425 & 8871 & 9658 & 8917 & 10662 \\
\hline Energy structure $(\%)^{\mathrm{b}}$ & $\mathrm{x}$ & $13.2: 38.2: 48.6$ & $13.3: 38.0: 48.7$ & 12.9:36.2:50.9 & 13.8:38.0:48.2 & $13.2: 38.8: 48.0$ \\
\hline \multirow{8}{*}{$\begin{array}{l}\text { Nutrients }(\mathrm{g}) \\
\text { Total protein }\end{array}$} & 2001 & 73 & 66 & 80 & 69 & 83 \\
\hline & 2002 & 73 & 67 & 82 & 69 & 83 \\
\hline & 2003 & 73 & 67 & 80 & 69 & 83 \\
\hline & average & 73 & 66.7 & 80.7 & 69 & 83 \\
\hline & 2012 & 73 & 68 & 73 & 71 & 81 \\
\hline & 2013 & 71 & 68 & 72 & 70 & 82 \\
\hline & 2014 & 74 & 71 & 73 & 73 & 84 \\
\hline & average & 72.7 & 69 & 72.7 & 71.3 & 82.3 \\
\hline \multirow[t]{8}{*}{ animal } & 2001 & 44 & 40 & 48 & 44 & 49 \\
\hline & 2002 & 44 & 41 & 50 & 44 & 49 \\
\hline & 2003 & 44 & 40 & 48 & 44 & 49 \\
\hline & average & 44 & 40.3 & 48.7 & 44 & 49 \\
\hline & 2012 & 47 & 44 & 46 & 47 & 52 \\
\hline & 2013 & 46 & 44 & 45 & 46 & 53 \\
\hline & 2014 & 48 & 46 & 46 & 48 & 55 \\
\hline & average & 47 & 44.7 & 45.7 & 47 & 53.3 \\
\hline \multirow[t]{8}{*}{ plant } & 2001 & 29 & 26 & 32 & 25 & 34 \\
\hline & 2002 & 29 & 26 & 32 & 25 & 33 \\
\hline & 2003 & 29 & 26 & 32 & 25 & 34 \\
\hline & average & 29 & 26 & 32 & 25 & 33.7 \\
\hline & 2012 & 26 & 24 & 27 & 24 & 29 \\
\hline & 2013 & 25 & 24 & 27 & 24 & 29 \\
\hline & 2014 & 26 & 25 & 27 & 25 & 29 \\
\hline & average & 25.7 & 24.3 & 27 & 24.3 & 29 \\
\hline \multirow[t]{8}{*}{ Fat } & 2001 & 99 & 90 & 109 & 94 & 113 \\
\hline & 2002 & 99 & 92 & 109 & 94 & 112 \\
\hline & 2003 & 99 & 90 & 109 & 94 & 113 \\
\hline & average & 99 & 90.7 & 109 & 94 & 112.7 \\
\hline & 2012 & 97 & 91 & 97 & 92 & 113 \\
\hline & 2013 & 90 & 84 & 88 & 85 & 104 \\
\hline & 2014 & 94 & 88 & 89 & 88 & 107 \\
\hline & average & 93.7 & 87.7 & 91.3 & 88.3 & 108 \\
\hline
\end{tabular}




\begin{tabular}{ccccccc} 
& & & & & & cont. tab. 5 \\
\cline { 6 - 7 } Carbohydrate & 2001 & 320 & 282 & 363 & 283 & 370 \\
& 2002 & 317 & 283 & 362 & 285 & 358 \\
& 2003 & 320 & 282 & 363 & 283 & 370 \\
average & 319 & 282.3 & 362.7 & 283.7 & 366 \\
& 2012 & 273 & 256 & 296 & 256 & 307 \\
& 2013 & 259 & 244 & 278 & 242 & 290 \\
& 2014 & 269 & 254 & 287 & 253 & 299 \\
average & 267 & 251.3 & 287 & 250.3 & 298.7
\end{tabular}

${ }^{a}$ Gross, i.e. including losses resulting from storage, preparation of meals, useful waste, etc.; excluding alcoholic beverages; including estimated consumption in catering establishments; calorific value and nutrients were calculated according to the coefficient drawn up by the National Food and Nutrition Institute. ${ }^{\mathrm{b}}$ When calculating the energy structure the following calorific values of elements were adopted $(1 \mathrm{~g})$ : carbohydrates and proteins $-17 \mathrm{~kJ}$ each; fats $-38 \mathrm{~kJ}$.

Source: GUS (2003), p. 224; GUS (2004), p. 311; GUS (2012); p. 308; GUS (2015), p. 310.

\section{Conclusions}

People from the dawn of history wanted to provide themselves with the necessary amount of food of the desired quality. By managing the world they intentionally or intuitively create conditions for meeting their own needs. Broadly using for the purpose the surrounding environments, of which they are an active ingredient, they strive to meet food security.

Polish literature discusses the issues of food security as such only in the 1990 s, although the theme of feeding the nation has been tackled much earlier, not using the term of food security.

The research, presented in this paper, aimed at determining the status and direction of changes to food security of Poland and its inhabitants at the beginning of the $21^{\text {st }}$ century, in particular: characterisation of the level of consumption of basic food products in 2000-2014 and establishing the level of food selfsufficiency of selected products, assessment of the conditions for durability and reliability of food supplies, characterisation of the conditions of economic availability of food and the diversity of the Polish inhabitants in this regard, determination of the level of consumption of energy, its structure and basic nutrients for different socio-economic groups of households for 2001-2003 and 20122014. Three-year periods and their averages were adopted to eliminate annual consumption fluctuations. Because the number of Polish families changes over time, the research used the consumption level per 1 family member.

A set of measures and indicators was developed to assess the status of national food security for Poland and its inhabitants.

The most important in the research was the dimension of state security and security of households, especially their family members (inhabitants). To ensure food security of the state it is necessary to meet the four conditions simultaneously: (1) physical availability of food; (2) durability and reliability of food sup- 
plies; (3) economic food availability; (4) health suitability of a respective food product and consumed food ration.

Assessing the first condition for food security of Poland on the example of selected products it was stated that it is sustained with a margin, except for fruit.

The issue of durability and reliability of supplies was assessed on the basis of food chain functioning. Positive trade balance in agri-food products gives economic grounds for shaping economic durability and reliability of food supplies and extends the range of supplied products.

Economic availability of food depends on obtaining fixed income and on the level of disposable income per family member. In the researched period (from 2001-2003 to 2012-2014) the disposable income grew, but differently in respective groups of households. Disposable income and expenditures on food and non-alcoholic beverages differed not only between social and professional groups of the population but also inside the groups. Despite various forms of state aid there are still households at risk of poverty.

In the researched period, a decrease in the energy value of a diet was also noted. The highest value is still characteristic for households of pensioners, followed by that of farmers and the lowest for households of self-employed people.

The structure of the diet is unfortunately faulty, because too much energy comes from fats and too little from carbohydrates. It should be also noted that the quality of consumed food is assessed very highly (no unacceptable volumes of pollution).

To conclude, the positive changes include increase in: (a) food self-sufficiency of the country; (b) economic and organisational grounds for durability and reliability of food supplies; (c) disposable income per 1 family member and decreasing share of expenditures on food from this income. Whereas the negative ones cover: low level of sustainability of energy sources - in 2001-2003 energy sources were more sustainable (proteins and carbohydrates - normal) than in 2012-2014 (only proteins and in the groups of farmers - energy from carbohydrates).

The very high quality of consumed food should also be noted. 


\section{Literature:}

Act of 25 August 2006 on food security and food safety, Journal of Laws of 2006, No. 171. item 1225; amendment of the Act of 8 January 2010 on amendment on food security and food safety and some other acts, Journal of Laws of 2010.

FAO (2002). The State of Food Insecurity in the World. Rome.

Gulbicka, B. (2008). Bezpieczeństwo żywności w Polsce. Studia i Monografie, no. 116. Warszawa: IERiGŻ, pp. 64-138.

GUS (2005). Rocznik statystyczny rolnictwa i obszarów wiejskich 2005. Warszawa, pp. 385386.

GUS (2006). Rocznik statystyczny rolnictwa i obszarów wiejskich 2006. Warszawa, p. 406.

GUS (2007). Rocznik statystyczny rolnictwa i obszarów wiejskich 2007. Warszawa, pp. 383, $392,396$.

GUS (2008). Rocznik statystyczny rolnictwa i obszarów wiejskich 2008. Warszawa, pp. 393, 402.

GUS (2009). Rocznik statystyczny rolnictwa 2009. Warszawa, pp. 299-300.

GUS (2010). Rocznik statystyczny rolnictwa 2010. Warszawa, pp. 292-299, 308, 312.

GUS (2013). Rocznik statystyczny rolnictwa 2013. Warszawa, pp. 319-320, 334.

GUS (2014). Rocznik statystyczny rolnictwa 2014. Warszawa, pp. 347-351, 362.

GUS (2015). Rocznik statystyczny rolnictwa 2015. Warszawa, p. 340.

GUS (2003). Rocznik statystyczny Rzeczpospolitej Polskiej 2003. Warszawa, pp. 203-208, $200,224$.

GUS (2004). Rocznik statystyczny Rzeczpospolitej Polskiej 2004. Warszawa, pp. 290-295, 311,532 .

GUS (2010). Rocznik statystyczny Rzeczpospolitej Polskiej 2010. Warszawa, p. 518.

GUS (2011). Rocznik statystyczny Rzeczpospolitej Polskiej 2011. Warszawa, pp. 468-469.

GUS (2012). Rocznik statystyczny Rzeczpospolitej Polskiej 2012. Warszawa, pp. 288, 291, 302.

GUS (2013). Rocznik statystyczny Rzeczpospolitej Polskiej 2013. Warszawa, pp. 286, 302, 315.

GUS (2014). Rocznik statystyczny Rzeczpospolitej Polskiej 2014. Warszawa, pp. 308, 486.

GUS (2015). Rocznik statystyczny Rzeczpospolitej Polskiej 2015. Warszawa, pp. 304-305, 310, 318, 325-329, 336, 553.

IERiGŻ, ARR, MRiRW (2004). Handel Zagraniczny Produktami Rolno-Spożywczymi. Stan i perspektywy, no. 20 , p. 4.

IERiGŻ, ARR, MRiRW (2011). Rynek Rzepaku, no. 40, p. 37.

IERiGŻ, ARR, MRiRW (2015). Rynek Rzepaku, no. 48, p. 42.

Jarosz, M., Respondek, W., Wolnicka, K. et al. (2012). Zalecenia dotyczące żywienia i aktywności fizycznej. In: M. Jarosz (ed.), Normy żywienia dla populacji polskiej-nowelizacja. Warszawa: IŻì், p. 154.

Kapusta, F. (1976). Zmiany struktury agrarnej i kierunków produkcji rolniczej w LegnickoGłogowskim Okręu Miedziowym. Warszawa: PWN, pp. 11-12.

Kapusta, F. (2003). Teoria agrobiznesu. Wrocław: Wydawnictwo AE, pp. 19-22.

Kapusta, F. (2006). Zarzadzanie działaniami logistycznymi. Poznań-Wrocław: Wydawnictwo Forum Naukowe, pp. 105-136. 
Kapusta, F. (2008). Agrobiznes, Warszawa: Difin, pp. 28-33.

Kapusta, F. (2012). Agrobiznes. Warszawa: Difin, pp. 27-32, 71-72, 263-264.

Kapusta, F. (2015). Bezpieczeństwo żywnościowe jako indykator zrównoważonego spożycia. Journal of Agribusiness and Rural Development, no. 4, pp. 695-703.

Kowalczyk, S. (2009). Bezpieczeństwo żywności w erze globalizacji. Warszawa: Oficyna Wydawnicza SGH, p. 303.

Kwasek, M. (ed.) (2012). Z badań nad rolnictwem społecznie zrównoważonym (17). Ocena stanu wyżywienia ludności $w$ Polsce $w$ aspekcie bezpieczeństwa żywnościowego. Warszawa: IERiGŻ-PIB, p. 160.

Kwasek, M. (2012). Ekonomiczna dostępność żywności. In: Z badań nad rolnictwem społecznie zrównoważonym. Ocena stanu wyżywienia ludności w Polsce w aspekcie bezpieczeństwa żywnościowego. Warszawa: IERiGŻ-PIB, pp. 36-37, 39.

Leśniak, K. (2012). Bezpieczeństwo żywnościowe i bezpieczeństwo żywności - aspekty prawne. Przeglad Prawa Rolnego, no. 1(10).

Małysz, J. (1991). Bezpieczeństwo żywnościowe strategiczna potrzeba ludzkości. Warszawa: Wydawnictwo Naukowe PWN.

Małysz, J. (2008). Bezpieczeństwo żywnościowe strategiczna potrzebą ludzkości. Warszawa: ALMAMER, Wyższa Szkoła Ekonomiczna.

Małysz, J. (1990). Bezpieczeństwo żywnościowe. In: E. Gorzelak (ed.), Gospodarka rynkowa a wyżywienie. Warszawa: SGPiS.

Małysz, J.(2009). Ekonomiczna interpretacja bezpieczeństwa żywnościowego. In: S. Kowalczyk (ed.), Bezpieczeństwo żywnościowe $w$ erze globalizacji. Warszawa: Oficyna Wydawnicza SGH.

Marks-Bielska, J., Lizińska, W., Serocka, I. (2015). Polski handel zagraniczny produktami rolno-spożywczymi i jego przewaga komparatywna w latach 2008-2013. Journal of Agribusiness and Rural Development, no. 4(38), p. 760.

Michalczyk, J. (2012). Bezpieczeństwo żywnościowe w obliczu globalizacji. Ekonomia, no. 1(18), Wrocław: Wydawnictwo Uniwersytetu Ekonomicznego we Wrocławiu.

Michna, W.(1998). Bezpieczeństwo żywnościowe. In: Encyklopedia agrobiznesu. Warszawa: Fundacja Innowacja, Wyższa Szkoła Społeczno-Ekonomiczna, pp. 63-65.

Mikuła, A. (2012). Bezpieczeństwo żywnościowe w Polsce. Roczniki Ekonomii Rolnictwa i Rozwoju Obszarów Wiejskich, vol. 99, issue 4, pp. 38, 44, 46.

Obiedzińska, A. (2012). Bezpieczeństwo żywnościowe. In: M. Kwasek (ed.) Z badań nad rolnictwem społecznie zrównoważonym. Ocena stanu wyżywienia ludności w Polsce $w$ aspekcie bezpieczeństwa żywnościowego. Warszawa: IERiGŻ-PIB, pp. 9-22.

Sapa,A. (2012). Bezpieczeństwo żywnościowe w krajach rozwijających się. Retrieved from: www.kpsw.edu, access date: 04.01.2012.

Schejtman, A. (1988). Food security trends and impact of the crisis. Cepal Review, p. 36.

Stachak, S. (2003). Podstawy metodologii nauk ekonomicznych. Warszawa: Książka i Wiedza, pp. 213-216.

Stachak, S.(1997). Wstep do metodologii nauk ekonomicznych. Warszawa: Książka i Wiedza, pp. 132-133. 
FRANCISZEK KAPUSTA

Uniwersytet Przyrodniczy

Wrocław

\title{
EWOLUCJA BEZPIECZEŃSTWA ŻYWNOŚCIOWEGO POLSKI I JEJ MIESZKAŃCÓW NA POCZĄTKU XXI WIEKU
}

\begin{abstract}
Abstrakt
Celem badań było określenie stanu i kierunku zmian bezpieczeństwa żywnościowego Polski i jej mieszkańców na początku XXI wieku, a w szczególności: scharakteryzowanie poziomu spożycia podstawowych produktów żywnościowych $w$ latach 2000-2014 oraz określenie poziomu samowystarczalności żywnościowej wybranych produktów, dokonanie oceny warunków trwałości i niezawodności dostaw żywności, scharakteryzowanie warunków ekonomicznej dostepności do żywności i zróżnicowania społeczności polskiej pod tym względem, ustalenie poziomu spożycia energii, jej struktury oraz podstawowych składników odżywczych dla poszczególnych grup społeczno-ekonomicznych gospodarstw dla lat 2001-2003 i 2012-2014.

Aby bezpieczeństwo żywnościowe państwa było zagwarantowane, spetnione musza być cztery warunki jednocześnie: 1) fizyczna dostepność żywności, co oznacza, że krajowa gospodarka żywnościowa gwarantuje spożycie co najmniej minimalnego zapotrzebowania fizjologicznego, import zaś dostarcza żywności ponad to minimalne zapotrzebowanie, 2) trwałość $i$ niezawodność dostaw żywności, 3) ekonomiczna dostepność żywności, co jest równoznaczne z tym, że także najsłabsze ekonomicznie gospodarstwa domowe i ich członkowie mają dostep do niezbędnej żywności (dzięki różnym formom pomocy żywnościowej), 4) zdrowotna odpowiedniość pojedynczego produktu żywnościowego $i$ spożywanej racji żywnościowej (niezbędny poziom energii, właściwa proporcja składników pokarmowych, brak niedopuszczalnej wielkości zanieczyszczeń).
\end{abstract}

Słowa kluczowe: bezpieczeństwo żywnościowe, samowystarczalność, struktura, poziom, spożycie.

Accepted for print: 28.04 .2017$.

Unless stated otherwise all the materials on the website are available under the Creative Commons Attribution 3.0 Poland license. Some rights reserved to the Institute of Agricultural and Food Economics - National Research Institute.

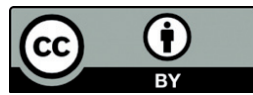

